Rev. Latinoam. Psicopat. Fund., São Paulo, v. 11, n. 3, p. 502-505, setembro 2008

Tratado médico filosófico sobre a alienação mental ou a mania

Phillipe Pinel

Tradução de Joice A. Galli

Porto Alegre: Ed. da UFGRS, [1800-1801] 2007, 272 págs.

\title{
Philippe Pinel e os primórdios da Medicina Mental
}

Cristiana Facchinetti

A iniciativa do SIMERS (Sindicato Médico do Rio Grande do Sul) de verter para o português o Tratado médico-filosófico sobre a alienação mental ou a mania deve ser comemorada: trata-se de uma das pedras angulares da história da psiquiatria moderna, peça-chave da primeira revolução psiquiátrica, i.e, da configuração da loucura em doença mental. É de se perguntar, aliás, como foi possível prescindirmos de uma tradução integral da obra até então, já que o tema da constituição da psiquiatria no Brasil tem sido objeto de investigações em diferentes áreas há três décadas, e a importância de Philippe Pinel (1745-1826) para tanto é indubitável. A cuidadosa tradução torna o convite à leitura dessa obra ainda mais atraente, ampliando a possibilidade de utilização do Traité como fonte primária para a pesquisa histórica. 
O livro, escrito sete anos após Pinel ter sido nomeado médico de Bicêtre, distingue-se, como nos diz Zilboorg (1963, p. 323), por tomar como objeto central da terapêutica a reforma e reorganização hospitalares. As reformas pinelianas fundaram uma nova tradição para a investigação e prática psiquiátricas, marcada pela articulação entre o saber e a técnica. Em consonância com os tempos de utopia da virada do século, cujos ecos ressoavam nas Revoluções Francesa e Industrial, suas propostas aderiram ao ideário revolucionário, sendo representadas em termos de "liberdade" no hospício, "igualdade" entre sãos e doentes (já que a doença passa a uma questão quantitativa e não mais qualitativa em sua natureza) e fraternidade, como filantropia e esclarecimento.

Basicamente, o Tratado pode ser compreendido em termos de um enfrentamento de dois problemas centrais: os limites do conhecimento sobre a alienação; e o estabelecimento de um campo de pesquisa e sistematização capaz de tratar e curar as diversas manifestações da loucura.

O primeiro enfrentamento é levado a cabo pela análise da alienação a partir de descrições densas dos doentes, traços de seu caráter físico e moral, sinais precursores, acessos, delírios, afecções morais, lesões do entendimento durante o acesso, declínio das crises, cura, recaídas, lesões anátomo-clínicas, enfim. O Traité fornece, principalmente nas quatro primeiras seções, argumentos que tornam a loucura uma verdade positiva, objeto específico do alienismo, agrupado em suas várias espécies, nas quais se sobressaem a mania sem delírio, a mania com delírio, a melancolia e a demência.

O segundo enfrentamento combina a perspectiva científica, que exige um trabalho apoiado em uma tradição de conhecimento preexistente, e a perspectiva da terapêutica. Este problema é enfrentado, em particular, na "Introdução" e nas seções V e VI, através da crítica ao conhecimento acumulado na fase pré-revolucionária (p. 51-62) e a proposta de retomada do conhecimento de gregos e latinos sobre as paixões como apoio teórico, bem como através da criação de instrumentos que permitem a Pinel propor táticas de enfrentamento dos sintomas e técnicas para realizá-las.

Através de descrição minuciosa nas seções V e VI, os afetos vão deixando de ser objeto do discurso filosófico e se tornam fenômenos naturais, objeto de conhecimento médico-fisiológico. Denominadas agora de "afecções morais"

1. Ressalto aqui que a idéia de liberdade é tomada de forma ideológica, estando fortemente vinculada à disciplinarização dos corpos, tal como Foucault (1976) já apontou. Assim, a ênfase de Pinel na circulação dos internos fora das celas, no trabalho, oferta de música, literatura, convive lado a lado com o uso de camisas de força, duchas, aprisionamento e punições para controle dos doentes, todos considerados parte do tratamento moral. 
(p. 82), as paixões da alma se tornam causa da loucura, marcadas como excessos relativos ao amor, à ordem social ou aos sentimentos, resistentes à regulação que deveria ser realizada pela razão (p. 238). Diante do excesso, a medicina mental busca a restauração do domínio racional por meios morais e físicos, de modo a curar os alienados, tornando-os novamente senhores de sua razão (Birman, 1978).

O hospício encontra na articulação entre sistematização e terapêutica sua legitimidade, demonstrando-se no Traité como fundamental para a acumulação reflexiva do conhecimento acerca da loucura e o estabelecimento de regras metodológicas de pesquisa (p. 240). O isolamento justifica-se também como terapêutica e técnica, uma vez que ao afastar o doente do mundo externo, Pinel pensava intervir em seu conflito interno (p. 227-229), apoiando as forças da saúde e a tendência natural da doença na direção da cura (p. 217-219). Além disso, evitava que os alienados perturbassem a ordem, ao mesmo tempo em que protegia sua "sensibilidade excessiva" das "zombarias" e da "ignorância" frente à enfermidade (p. 216).

Ainda, o estudo das relações dos alienados com seus familiares - e mesmo com os profissionais do hospício - faz parte dessa problematização, já que se pretende intervir nessas trocas de modo terapêutico. Ressalta-se, a análise não se restringe ao asilo, fornecendo pistas para perseguir os processos insanos na sociedade afora, como ocorre na seção IV.

Como último ponto, creio ser interessante chamar a atenção para a linguagem adotada por Pinel - sem dúvida, este é um livro à procura de leitores. Simultaneamente à sistematização e à discussão metodológica, Pinel está buscando em seu discurso interessar, construir alianças, produzir provas, mobilizar aliados e endurecer as críticas aos estudos apoiados em conhecimento especulativo e às práticas sem apoio na experiência sistematizada cientificamente, com o objetivo de convencer, transformar seus resultados em fatos. Assim, nosso autor segue um discurso em que se sucedem estudos de caso, provas, curas, tabelas estatísticas, análise e citações. O leitor é envolvido por conexões de argumentos, citações e referências.

Em certo sentido, essa combinação se revela em hesitações que demonstram as inúmeras dificuldades de Pinel contornar os obstáculos conceituais para expressar suas proposições no campo psiquiátrico. Ao longo da discussão, vemos então um discurso em constituição, o que se traduz, eventualmente, em um "estilo enviesado" (Oda, 2007, p. 11), nem sempre de fácil leitura; mas a articulação da prática clínica com a prática social é cristalina, jóia rara para revelar o campo de forças históricas e culturais que regem os princípios do alienismo. Este é, aliás, um dos melhores motivos para continuarmos a ser leitores de Pinel. 
Birman, J. A psiquiatria e o discurso da moralidade. Rio de Janeiro: Graal, 1978.

Foucault, M. La volonté du savoir. Paris: Gallimard, 1976.

ODA, A.M.G.R. Sobre a Revisão da Tradução. In: Pinel, Ph. Tratado médico-filosófico sobre a alienação mental ou a mania. Tradução de Joice A. Galli. Porto Alegre: Ed. da UFGRS, 2007.

Zilboorg, G.H. Historia de la psicologia medica. Buenos Aires: Psique, 1963.

\section{Cristiana Facchinetti}

Psicanalista; doutora em Teoria Psicanalítica pela Universidade Federal do Rio de Janeiro UFRJ (Rio de Janeiro, RJ, Brasil); pós-doutora em História das Ciências e da Saúde pela Fundação Oswaldo Cruz - Fiocruz (Rio de Janeiro, RJ, Brasil); pesquisadora do Departamento de Pesquisa e professora do PPGHCS, ambos da COC/Fundação Oswaldo Cruz - Fiocruz Av. Brasil, 4036/sala 406 - Manguinhos 21040-361 Rio de Janeiro, RJ, Brasil e-mail: cfac@coc.fiocruz.br 